Krzysztof Bracha

Kielce

\title{
Noty łacińskie w Kazaniach świętokrzyskich
}

Partie łacińskie w Kazaniach świętokrzyskich nie mają bogatej tradycji badawczej, i w przeciwieństwie do tekstu polskiego, były przez długi czas pomijane w analizach oraz edycjach, a nawet rzec można lekceważone. Wrażenie, jakie wywarł na pokoleniach badaczy relikt cudownie ocalonych fragmentów języka polskiego sprzed siedmiu stuleci oraz predylekcja do traktowania Kazań jedynie jako zabytku języka polskiego, $\mathrm{z}$ niedocenianiem homiletycznego charakteru gatunku, zepchnęło na margines ten aspekt „relikwii świętokrzyskiej”. Sprawy nie ułatwiał również ówczesny stan badań nad kaznodziejstwem średniowiecznym w ogólności w rodzimej i obcej humanistyce, których burzliwy rozwój przypadł dopiero na ostatnie cztery dziesięciolecia, i który jeszcze dziś daleki jest od ostatecznych rozstrzygnięć. Kilka jednak rozwiniętych w międzyczasie nurtów zainteresowań, dotyczących przede wszystkim transmisji tekstów kaznodziejskich, a szczególnie zjawiska bilingwizmu i kazań wernakularnych, trzeba uznać za szczególnie pomocne w interesującym nas kontekście.

Taki stan rzeczy miał oczywiście wpływ na dotychczasowe analizy i płynące z nich wnioski. Dopiero najnowsza edycja oraz kilka poprzedzających ją szczegółowych studiów ponownie wyniosły z zapomnienia ten niezwykle istotny, a może nawet kluczowy aspekt Kazań. W najnowszej edycji przypomniał o tym Mieczysław Mejor (s. 81), któremu zresztą zawdzięczamy odnowienie, a raczej inicjację badań nad łacińskimi partiami tekstu1.

${ }^{1}$ M. Mejor, Łacina w Kazaniach Swiętokrzyskich, [w:] Kazania Świętokrzyskie. Nowa edycja..., s. 81; tenże, Pochodzenie Kazań świętokrzyskich, s. 223; tenże, Eacińskie cytaty w „Kazaniach świętokrzyskich”, „Pamiętnik Literacki”, 95:2004, z. 1, s. 19-32 oraz T. Mika, Tajemnice „Kazań świętokrzyskich”, „Teraz”, 2006, nr 1 (25), s. 15; Z. Krążyńska, T. Mika, Języki „Kazań świętokrzyskich” [http://www.staropolska.pl/sredniowiecze/opracowania/Mika.html]. 
W zachowanych szczątkach Kazań fragmentów łacińskich jest niewiele, w sumie 29 różnej proweniencji cząstek. Świadczą one jednak dobitnie, że w oryginalnej formie, dziś już nie do zweryfikowania, takich partii było zapewne znacznie więcej, i że stanowiły one immanentną część Kazań, nadając im dwujęzycznego charakteru w typie macaronic sermons, jak to kiedyś sformułował Siegfried Wenzel $^{2}$.

Odpowiedź na pytanie, dlaczego w takiej formie językowej dochowały się w dostępnym rękopisie, jest jednym $\mathrm{z}$ kluczowych pytań o genezę, pochodzenie, redakcję i transmisję Kazań, które długo jeszcze pozostaną przedmiotem dyskusji. Fragmentaryczny stan zachowania zabytku, oraz inne aspekty tekstu, zadania tego bez wątpienia nie ułatwia. Spróbujmy jednak przyjrzeć się wybranym fragmentom, które dają mocniejsze podstawy do snucia hipotez i szukania odpowiedzi lub tylko stawiania uzasadnionych pytań. Fragmenty lacińskie w Kazaniach nie są bowiem jednorodne i są, jak się wydaje, w tekście inkorporowane z różnych intencji. Nie jest moim celem kompleksowe ujęcie tego zagadnienia, gdyż wymaga ono dalszych, pogłębionych badań, lecz próba analizy tych łacińskich partii, które na podstawie dzisiejszego stanu wiedzy o kaznodziejstwie z epoki można przyporządkować do stosowanych zasad redagowania tekstu kaznodziejskiego i jego transmisji.

Zgodnie z kolejnością konstrukcji formularzowej kazania, zaczniemy od łacińskich perykop. Wiemy bowiem, że zasadniczo - choć i to wymaga bliższego wyjaśnienia - ekspozycja werbalna kazań ad populum odbywała się w języku narodowym, o czym świadczą m.in. liczne glosy w języku polskim ${ }^{3}$. Już bowiem we wczesnośredniowiecznych synodach z IX w.

${ }^{2}$ S. Wenzel, Macaronic Sermons. Bilingualism and Preaching in Late-Medieval England, Michigan 1994.

${ }^{3}$ R. Lubicz, Glosy polskie zawarte w rękopisie z kazaniami lacińskimi z polowy wieku $X V$, „Sprawozdania Komisji Językowej Akademii Umiejętności”, t. 5, 1893, s. 240-338; tenże, Kilka zabytków języka staropolskiego, cz. I-V, „Prace Filologiczne”, t. 4, Kraków 1893, s. 587-638; tenże, Kilka zabytków języka staropolskiego, cz. VI - XIII, tamże, t. 5, Kraków 1894, s. 53-89; tenże, Reguta Trzeciego Zakonu św. Franciszka i drobniejsze zabytki jezzyka polskiego z końca w. XV-ego i początku XVI-ego, tamże, t. 4, 1893, s. 754-756; A. Brückner, Drobne zabytki języka polskiego XV wieku. Pieśni. Modlitwy. Glosy, [w:] „Rozprawy Akademii Umiejętności. Wydział Filologiczny”, t. 25, 1897, s. 206-291; tenże, Glosy wroctawskie, „Prace Filologiczne”, t. 3, Kraków 1891, s. 281-292; L. Malinowski, Glosy polskie w kilku rękopisach tacińskich wieku XV. w bibliotekach kapitulnej $i$ uniwersyteckiej w Pradze, „Rozprawy Akademii Umiejętności. Wydział Filologiczny”, Seria 2, t. 22, Kraków 1895, s. 350-392; tenże, Quadragesimale super epistolas. Glosy polskie z konca pierwszj polowy wieku XV, „Sprawozdania Komisji Językowej Akademii Umiejętności”, t. 1, 1880, s. 295-314; J. Woronczak, Teksty polskie w rękopisie nr 43 Biblioteki Kapitulnej we Wroctawiu z polowy XV w., Wrocław 1956 (Prace Wrocławskiego Towarzystwa Naukowego, Ser. A, nr 55); M. Muszyński, Glosy i zapiski polskie w starych drukach Bi- 
(np. w Tours i Moguncji z 813 r.) zalecano głoszenie kazań dla ludu w językach narodowych ${ }^{4}$. Według najstarszego rodzimego świadectwa, dokumentu erekcyjnego dla kościoła Panny Marii w Krakowie z 1226 r., o ile nie jest on falsyfikatem, wspomina się że przynajmniej w tym mieście głoszono już wówczas kazania wernakularne: „Polonico sermone (...) predicaretur"5. Drugi w kolejności synod abpa gnieźnieńskiego Jakuba Świnki z 1285 r. stanowił, że rudymentarne modlitwy „loco sermonis exponere debeant populo in polonico et festa indicere. Si qui autem, adeo periti fuerint, exponant Evangelium" . W ponad sto lat później we wstępie do swojej obszernej i jednej z najstarszych rodzimych postylli, datowanej na 1412 r., Łukasz z Wielkiego Koźmina zapowiadał, że są to „sermones per modum postille vulgariter ad fidelem Christi populum per me prolatos"7 lub w innym miejscu ,sermones vulgares, quos faciebam dum constituebamini in Lubnicza loco nativitatis Vestre (...) et hic in Banszowa, que fuit, ad quam fui praesentatus per Vos et fratres Vestros paternos, Vestre collationis parochia, que a prefata villa Lubnicza distat in aliquali distancia"8. Jak wynika z powołanego prologu Lukasz

blioteki Kórnickiej, „Pamiętnik Biblioteki Kórnickiej”, t. 8, 1963, s. 113-164 (gł. s. 147-148); tenże, Glosy, zapiski i niektóre teksty polskie w starych drukach i rękopisach Biblioteki Kómickiej do roku 1550. Cz. 2, „Pamiętnik Biblioteki Kórnickiej”, t. 9-10, 1968, s. 154-282; J. Wojtkowski, Glosy i drobne teksty polskie do 1550 roku. Z inkunabutów Archiwum Archidiecezjalnego w Poznaniu (PTPN. Wydział Filologiczno-Filozoficzny. Prace Komisji Językoznawczej, t. 18. Zabytki języka i literatury polskiej, nr 7), Poznań 1965; Glosy polskie rękopisu Sermones de tempore et de sanctis nr XV 32 biblioteki oo. Dominikanów w Krakowie z drugiej potowy XV wieku, opr. R. Laskowski i J. Reczek, Wrocław-Kraków 1968; M. Kowalczyk, E. Belcarzowa, F. Wysocka, Glosy polskie Jakuba z Piotrkowa i innych autorów w rękopisach Biblioteki Jagiellońskiej, „Biuletyn Biblioteki Jagiellońskiej”, 23:1973, nr 1-2, s. 79-115; E. Belcarzowa, Glosy polskie w zbiorze kazań tacinskich w rękopisach Biblioteki Jagiellońskiej nr 67/54, tamże, 1973, s. 117-129; tejże, Glosy polskie w tacińskich kazaniach średniowiecznych, cz. 1-4, Wrocław-Lódź-Kraków 1981-2001; tejże, Jak w XV wieku tlumaczono tacinskie kazania na jezyk polski. Na przyktadzie glos polskich w XV-wiecznych zbiorach kazań, [w:] Między oryginatem a przektadem i czy istnieje teoria przektadu?, red. J. Konieczna-Twardzik, U. Kropiwicz, Kraków 1995, s. 165-173.

${ }^{4}$ B. M. Kienzle, Introduction, [w:] The Sermon, ed. by B. M. Kienzle, Turnhout 2000, s. $170,172-173$.

${ }^{5}$ Kodeks dyplomatyczny Katedry Krakowskiej, nr 398, cz. 2, wyd. F. Piekosiński, Kraków 1883 (MMH, t. 8), s. 187-188 oraz tamże, s. 189-190: komentarz. O późniejszej sytuacji językowej w kaznodziejstwie tego kościoła w związku z napływem osadników niemieckich, por. J. Ptaśnik, Miasta w Polsce, Lwów 1922, s. 143-146; tenże, Miasta i mieszczaństwo w dawnej Polsce, Warszawa 1949, s. 269.

${ }^{6}$ Z. A. Kliszko, Przepisy synodalne w Polsce średniowiecznej o kaznodziejstwie, „Studia Theologica Varsaviensia", 13:1975, nr 1, s. 122.

${ }^{7}$ Lucas de Magna Cosmin, Sermones per modum postille, Wrocław, Oss. rps 2008, f.1ra.

${ }^{8}$ Lucas de Magna Cosmin, Prologus, [w:] tegoż, Sermones per modum postillae, Kielce, BSem., rps 27, f. 9 ra; Wrocław, Oss., rps 2008, f. 1 ra; Ex codicibus kielcensibus, wyd. 
kazał we wsi Łubnice w miejscowym kościele parafialnym, który należał wówczas do parafii Beszowa Rycerska (dziś Beszowa), w dawnym województwie sandomierskim na zachód od pobliskiego Połańca (dzisiejsze woj. świętokrzyskie). Łukasz był bowiem mówcą i moralizatorem wyjątkowym, z przekonania i z przygotowania kaznodzieją ludowym, który sam o sobie powiadał „quia Polonus sum, Polonis loquor”.

Kazanie mogło być również tłumaczone symulatanicznie na język miejscowy, a czyniono tak zwykle w czasie gościnnych występów słynnych kaznodziejów ludowych, np. Wincentego Ferrera lub Jana Kapistrana. Przebywający na zaproszenie polskiego króla i abpa Zbigniewa Oleśnickiego w Krakowie w 1454 r. Jan Kapistran, według relacji Długosza kazał po łacinie, tłumaczony następnie na język polski do ludu przez minimum dwie godziny plus dwie godziny przekładu, czyli w sumie wedle słów kronikarza „nauka jego codziennie przez cztery godziny trwała"10. W dokumencie fundacji stałej predykatury w katedrze krakowskiej podkreślono, że kaznodzieją ma być duchowny ze stopniem akademickim znający doskonale język polski (aut perfectum in idiomate Polonico), i mogący głosić kazania w obu językach po łacinie i w języku polskim (in Polonico et Latino idiomatibus $)^{11}$. Statut synodu warmińskiego z 1449 r. zwracał uwagę na głoszenie kazań do Prusów in prutenico lub jeśli rozumieją po niemiecku ${ }^{12}$. Z czasów chrztu Litwy i Żmudzi mamy zaś aczkolwiek nie do końca wiarygodne relacje Długosza o „kazaniach” samego Jagiełły „linguam Samagitticam" lub co bardziej prawdopodobne kaznodziei królewskiego dominikanina Mikołaja Wężyka do Żmudzinów ,per interpretem praedican-

W. Kętrzyński, Lwów 1888, (MPH, t. 5), s. 1001; „magistro Luca rectore parochialis ecclesie in Banzowa", Kodeks dyplomatyczny Matopolski, wyd. F. Piekosiński, t. 4, Kraków 1905, nr 1123, z 29.11.1410 r., s. 128.

${ }^{9}$ J. Wolny, Lacinski zbiór kazań Peregryna z Opola i ich związek z tzw. „Kazaniami gnieźnieńskimi”, [w:] Średniowiecze. Studia o kulturze, t. 1, red. J. Lewański, Warszawa 1961, s. 218-219.

10 „Predicatio quoque sua aliis duabus horis in vulgari resumpta est. Sic quatuor horis continuis (...) primum in Latina deinde in vulgari lingua continuata", Ioannis Dlugossi Annales seu Cronicae incliti Regni Poloniae, Lib. 12, red. J. Wyrozumski, K. Ożóg, Varsaviae - Cracoviae, 2005, s. 171-172. Por. K. Kantak, Bernardyni polscy, t. 1, Lwów 1933, s. 5-7. Z kolei kazania Wincentego Ferrera trwały od dwóch do sześciu godzin. P. T. Dobrowolski, „Fides ex auditu”: uwagi o funkcji kazania w późnym średniowieczu, „Przegląd Historyczny", 81:1990, s. 40.

${ }^{11}$ Codex Diplomaticus Universitatis Studii Generalis Cracoviensis, pars 2, Cracoviae 1873 , s. $141,142$.

${ }^{12}$ Cyt. za I. Skierska, Obowiązek mszalny w średniowiecznej Polsce, Warszawa 2003, s. 183-184; A. Radzimiński, Życie i obyczajowość średniowiecznego duchowieństwa, Warszawa 2002, s. 123-124; tenże, Chrystianizacja i ewangelizacja Prusów, Toruń 2008, s. 32-34. 
do"13. W świetle zaś wypowiedzi Macieja z Grochowa: ,predicator ibi debet predicare, ubi auditores eum possunt intelligere, Boemus in Boemia etc"14. W szczególnych wypadkach od kaznodziejów wymagano nawet znajomości miejscowych dialektów. Przykładowo w Żaganiu w klasztorze augustianów, gdzie poświadczony jest „praedicator Polonorum”, od zakonników wymagano znajomości „lingua Sleziana, ydeoma Saganense”, czyli jak można sądzić, śląskiego dialektu w wariancie żagańskim ${ }^{15}$. Wśród zakonników wielu kazało w dwóch językach narodowych, np. u bernardynów (utriusque idiomatis videlicet Polonici et Germanici). Słynny czeski kaznodzieja i myśliciel prehusycki Jan Milicz z Kromerzyża kazał dziennie nawet pięć razy, trzy razy po czesku, raz po łacinie i raz po niemiecku ${ }^{16}$. Niekiedy zaś samo audytorium było dwujęzyczne in vulgari. $\mathrm{W}$ relacji pewnego niemieckiego augustianina $\mathrm{z}$ Wrocławia $\mathrm{z}$ końca $\mathrm{XV}$ w. wysłanego do Kalisza, zadanie głoszenie kazań niemieckich w tym mieście mijało się z celem, gdyż większość tamtejszych Niemców znała język polski i w rezultacie na kazania niemieckie przychodziło sześć - osiem osób, jak z rozżaleniem wspominał zakonnik ${ }^{17}$. Ze Lwowa z XV w. mamy z kolei przykłady głoszenia kazań podwójnych niemieckich i polskich na dwóch osobnych ambonach w jednym czasie ${ }^{18}$. Kaznodzieja polski w tzw. kolekcji Piotra z Miłosławia odwoływał się w tej mierze do autorytetu Biblii, i wykładał, że Chrystus dał apostołom dar mówienia różnymi językami w kazaniach, choć sam mówił tylko po hebrajsku ${ }^{19}$.

${ }^{13}$ Cyt. za J. Fijałek, Uchrześcijanienie Litwy przez Polskę, [w:] Polska i Litwa w dziejowym stosunku, Kraków 1914, s. 72-74.

14 A. Brückner, Kazania średniowieczne, cz. 1, Kraków 1895, s. 6-7 (43-44), 25 (62).

${ }^{15}$ S. Rospond, Kaznodziejstwo polskie w XIV/XV w. na Ślasku, „Kwartalnik Opolski”, 27:1981, nr 2, s. 93-96. Por. też W. Urban, Jęzk polski w duszpasterstwie diecezji wroctawskiej, „Polonia Sacra”, 10:1958, nr 2, s. 239-244; J. Kłoczowski, Ze studiów narodowościowych na Ślasku w XV i poczatkach XVI wieku, „Przegląd Zachodni”, 7:1951, nr 11/12, s. 541-557, gdzie wiele przykładów śląskiego współistnienia kaznodziejów dla Polaków i dla Niemców.

${ }^{16}$ P. C. A. Morée, Preaching in Fourteenth-Century Bohemia. The Life and Ideas of Milicius de Chremsir (†1374) and His Signuficance in the Historiography of Bohemia, Eman 1999, s. 39.

17 ,...cum et Tewtorum pauci sunt, qui non scirent vtrumque ydeoma, quod quidem notantur in sermone, vbi vix sex aut octo uel parum citra videntur in toto" - List zakonnika $z$ Kalisza do opata wroctawskiego, ed. H. Kowalewicz, [w:] Ze starych rękopisów, Warszawa 1979 (Silva medii et recentioris aevi, t. 6), s. 44.

18 J. Skoczek, Kwestia języka kazań lwowskich w w. XIII-XVI, „Przegląd Teologiczny”, 8:1927, s. 340-341.

$19, \ldots$ in linguis habuerunt potestatem praedicandi, quia loquebantur linguis omnium hominum et hoc Christus non faciebat, quia solum vna lingua loquebatur, scilicet ebreica", Sermo 91, [w:] Sermones dominicales et festivales z tzw. kolekcji Piotra z Mitostawia, Warszawa, BN, rps 3021, f. 280 vb. 
Nie oznacza to, że nie znamy przypadków trudności językowych i braku odpowiednich kompetencji w tej mierze predykantów, sygnalizowanych niedawno przez Izabellę Skierską ${ }^{20}$.

Warunkiem nie była etniczność, lecz kompetencje językowe i kaznodziejskie predykanta ${ }^{21}$. Nastawienie na głoszenie kazań w języku narodowym było, co podkreśla literatura, bardziej typowe w krajach niemieckich oraz w Środkowej Europie ze względu na większą obcość łaciny, niż w romańskiej części kontynentu, gdzie jak się ostatnio dowodzi, możliwe były kazania dwujęzyczne ${ }^{22}$. Siegfried Wenzel sugerowat, że kazania wedle wielu wypowiedzi współczesnych były wygłaszane na trzy generalne sposoby: po łacinie, in vulgari oraz w sposób mieszany i na tej podstawie wyodrębnił ich kilka kategorii. Według przywołanej przez S. Wenzela wypowiedzi m.in. Tommaso Antonio ze Sieny (1395): „Sermonem devotum feci in latino coram populo et iuxta morem aliqualiter in vulgari”, jednakże cytowane przezeń statuty kartuzjańskie z 1510 r. stanowią, że „In dispositione facientis sermonem sit loqui latine vel vulgariter vel mixtim"23. Michel Zink a później Nicole Bériou wyodrębnili z kolei trzy typy kazań we francuskiej strefie językowej XII/XIII w.: pierwsze najstarsze, krótkie, proste i niezgrabne, które występowały zwykle w małych

${ }^{20}$ I. Skierska, Obowiązek mszalny w Polsce średniowiecznej, s. 182 i in.

${ }^{21}$ Codex Diplomaticus Universitatis Studii Generalis Cracoviensis, pars 2, Cracoviae 1873, s. 141, 142; J. Wiesiołowski, Problemy spoteczne klienteli bernardynów poznańskich na przetomie XV/XVI wieku, [w:] Zakony franciszkańskie $w$ Polsce, t. 1: Franciszkanie w Polsce średniowiecznej, cz. 1, red. J. Kłoczowski, Lublin - Kraków 1982, s. 362. Nieostrość podziału podkreślali L.-J. Bataillon OP, La prédication populaire d'un dominicain italien à la fin du XIII ${ }^{e}$ siècle (Götingen Univ. Bibl. Theol. 156 ${ }^{A}$ ), „Archivum Fratrum Praedicatorum", t. 65, 1995, s. 177; N. Bériou, Latin and the Vernacular. Some Remarks about Sermons Delivered on Good Friday during the Thirteenth Century, [w:] Die deutsche Predigt im Mittelalter. Internationales Symposium am Fachbereich Germanistik der Freien Universität Berlin vom 3.-6. Oktober 1989, red. V. Mertens, H.-J. Schiewer, Tübingen 1992, s. 279.

${ }^{22} \mathrm{Na}$ temat tzw. bilingwizmu kazań toczy się nadal dyskusja: M. B. Briscoe, Artes Praedicandi, Turnhout 1992 (Typologie des sources du Moyen Age occidental, red. L. Genicot, Fasc. 61), s. 61; B. M. Kienzle, The Typology of the Medieval Sermon and Its Development in the Middle Ages: Report on Work in Progress, [w:] De l'homlie au sermon. Histoire de la prédication médiévale. Actes du Colloque international de Louvain-la-Neuve (9-11 juillet 1992), red. J. Hamesse, X. Hermand, Louvain-la-Neuve 1993 (Université Catholique de Louvain. Publication de l'Institut d'Études Médiévales-Textes, d'Études, Congrés, vol. 14), s. 87; L. Lazerrini, Da quell'arzillo puplito. »Sermo humilis« e sermoni macaronici nel quaresimale autografo di Valeriano da Soncino O.P, „Medioevo e Rinascimento”, 3:1989, s. 171-240; N. Bériou, Latin and the Vernacular, s. 278-279; H. Martin, A propos du bilinguisme des predicateurs du bas Moyen Age: latin et français dans les sermons d'un orateur parisien du XVe siècle, [w:] Christianitas et cultura Europae. Ksiega Jublieuszowa Profesora Jerzego Kloczowskiego, cz. 1, red. H. Gapski, Lublin 1998, s. 103-111.

${ }^{23}$ S. Wenzel, Macaronic Sermons, Michigan 1994, s. 127-28. 
kolekcjach, w rękopisach z kazaniami łacińskimi i były spisane przez anonimowych autorów jako memorandum lub teksty wzorcowe dla młodych adeptów artis praedicandi. Są one w przeważającej części starofrancuskie, ale cytaty z autorytetów i pojęcia kluczowe są po łacinie. Drugi typ to większość, która jest prawie w całości spisana po francusku i którą M. Zink określit jako „Preaching in an armchair”. Są to kazania bardziej staranne, często przełożone z łaciny, ale nie służyły do kazania, lecz raczej do czytania i medytacji, czyli do prywatnej lektury w całości lub w części ${ }^{24}$. Te dwa typy N. Bériou uzupełniła trzecim, a mianowicie kazaniami rymowanymi z przeznaczeniem do medytacji, np. przed pobożnym obrazem ${ }^{25}$. Przywołana badaczka podała niezwykle ciekawy przykład dwujęzyczności kazań Ranulph’e de la Houblonniere. Słuchacz jego sermones zapisał bowiem, że z powodu ostrej krytyki duchowieństwa splamionego grzechem rozpusty i lęku przed skandalem, te słowa Ranulphe'a „dicas eis latinis verbis, non laicalibus, propter scandalum” 26 . Zjawisko bilingwizmu kazań jest jednak bardziej skomplikowane i stanowi wciąż przedmiot otwartej debaty naukowej. Nie chodzi przy tym wyłącznie o językową transmisję (redakcję) kazań, lecz również o nieostry podział audytorium, dla którego były przeznaczone. Teoretycznie wyraźnie rozgraniczano oba gatunki, skoro w Statuta capituli ecclesiae cathedralis wratislawiensis z 1482/83 r. zapisano: „praedicatores facientes latinos sermones ad clerum et vulgarum ad populum” oraz „fit latinus sermo ad clerum et praedicatio ad populum in vulgari"27. Mikołaj z Błonia i Jakub z Paradyża kierowali swe kolekcje dla obu grup, albowiem ,sermones ... valde deservientes populo, sed et clero" 28 . W praktyce zdarzały się więc kazania dla obu grup społecznych wymuszone lokalną sytuacją. Generalnie w praktyce duszpasterskiej trudno wykluczyć całkowity udział duchownych wśród słuchaczy kazań dla świeckich. Przy-

${ }^{24}$ Podobną redakcję kazań Maurice de Sully przełożoną z pierwotnej wersji zapisanej po łacinie i zaadaptowaną wtórnie po francusku sugeruje ostatnio B. Spieralska, Les sermons ad populum de Maurice de Sully et leur adaptation française, „Przegląd Tomistyczny", t. 13:2007, cz. 1, s. 9-112.

${ }^{25}$ M. Zink, La predication en langue romane avant 1300, Paris 1976; tenże, La predication en langues vernaculaires, [w:] Le Moyen Age et la Bible, red. P. Riche, G. Lobrichon, Paris 1984 (Bible de tous les temps, 4), s. 489-516; N. Bériou, Latin and the Vernacular, s. 269.

${ }^{26}$ N. Bériou, Latin and the Vernacular, s. 278.

${ }^{27}$ Statuta capituli ecclesiae cathedralis wratislaviensis ex anno 1482/83, wyd. W. Urban, K. Dola, Wrocław - Opole 2004, s. 306-309.

${ }^{28}$ T. Szostek, Exempla i autorytety w kazaniach Jakuba z Paradyża i Mikotaja z Btonia, [w:] Kultura elitarna a kultura masowa w Polsce późnego średniowiecza, red. B. Geremek, Wrocław-Gdańsk 1978, s. 290. 
kładowo w kościele Bożego Ciała na Kazimierzu w Krakowie słuchaczami kazań byli zarówno zakonnicy siedzący w stallach jak też świeccy ${ }^{29}$.

$\mathrm{W}$ każdym razie $\mathrm{z}$ tych m.in. powodów Nicole Bériou na podstawie kazań z terenu Francji podważyła zasadność generalnego podziału kazań dla świeckich i kleru ${ }^{30}$.

Spod tego obowiązku, jak się zdaje, wyłączano tylko perykopę ewangeliczną, którą zgodnie z nakazami należało najpierw przytoczyć po łacinie, a potem dopiero wyłożyć w miejscowym języku. „Ad omnes sermones debes primum versum Latina lingua pronunciare, deinde patria lingua explanare”, wykładał Honoriusz Augustodunensis ${ }^{31}$. Robert de Basevorn przestrzegał zaś przy tej okazji, by w tłumaczeniu nie dochodziło do zniekształceń lub skrótów oraz aby temat pochodził z Biblii, a nie $\mathrm{z}$ antyfonarzy ${ }^{32}$. W jednej $\mathrm{z}$ anonimowych instrukcji dla kaznodziei z rękopisu Biblioteki Jagiellońskiej 1299 z XV w. wyłożono tą zasadę z pedantyczną precyzją: „Tunc stando in Kathedra respicias evangelium vel epistolam, dicas tria vel quatuor verba, quid placet in latino et postea dicas in vulgari" ${ }^{33}$. Inne podobne zapisy odnoszą się do konkretnych języków, np. „Modus sermonizandi in capitulo” z XV w. polecał: „Primo dic thema in latino, deinde thema dic in theutonico" 34 . Podobnie w jednym z kazań z terenu Francji z XIII w. do tej reguły odnoszą się słowa zaraz po łacińskim temacie: ,in epistola hodierna modo lecto, et ualet tantum in gallico" 35 . W każdym razie już ten przykład dowodzi, że kazanie średniowieczne nie było monolitem językowym i że łacina była

${ }^{29}$ Por. K. Latak, Kanonicy regularni laterańscy na Kazimierzu w Krakowie do końca XVI wieku, Ełk 1999, s. 274.

${ }^{30}$ N. Bériou, Latin and the Vernacular, s. 279. Nieostrość podziału podkreślał także L.-J. Bataillon OP, La prédication populaire d'un dominicain italiena la fin du XIII siècle (Göttingen Univ. Bibl. Theol. 156 ${ }^{A}$ ), „Archivum Fratrum Praedicatorum”, t. 65, 1995, s. 177.

${ }^{31}$ Honorius Augustodunensis, Sermo de nativitate Domini, [w:] Speculum ecclesiae, wyd. Patrologia Latina, ed. J.-P. Migne, t. 172, Parisiis 1854, s. 829-830.

32 Robert de Basevorn, Forma praedicandi, ed. Th.-M. Charland, Artes praedicandi. Contribution a l'histoire de la rhéorique au Moyen Age, Paris 1936 (Publications de l'Institut d'Études Médiévales d'Ottawa, t. 7), c. 7, c. 16, s. 244-245, 250-251: „Videat etiam quo thema suum sit de textu Bibliae, non de antiphonario (...) Immo, vitiosum reputatur, si quis in themate litteram accipiat translationis alterius quam communiter usitatae".

${ }^{33}$ Kraków, BJ, rps 1299, f. 1r oraz cyt. przez A. Brücknera, Kazania średniowieczne, cz. 1, s. 42 (79); P. Sczanieckiego, Stużba Boża w dawnej Polsce. Seria I, Poznań - Lublin 1962, s. 78; K. Bracha, Stowa i gesty. Ryt akcji kaznodziejskiej w Polsce późnego średniowiecza, [w:] Rituály, ceremonie a festivity ve střední Evropě 14. a 15. století, red. M. Nodl, Fr. Smahel (Colloquia medievalia Pragensia, vol. 12), Praha 2009, s. 301-317 oraz A.T. Thayer, The Postilla of Guillermus and Late Medieval Popular Preaching, „Medieval Sermon Studies", t. 48, 2004, s. 63.

${ }^{34}$ Cyt. za J. Wolny, Eaciński zbiór kazań, s. 220, przyp. 13.

${ }^{35}$ N. Bériou, Latin and the Vernacular, s. 281. 
w nim niemal zawsze obecna ex definitione, czyli z postanowienia podręczników artis praedicandi.

Taki właśnie przypadek poświadcza, co zauważył Paweł Stępień, „Kazanie II: Na dzień św. Katarzyny” z perykopa „Surge, propera, Amica mea... (PnP 2,10; 2,13)"36. Johannes B. Schneyer notuje tę perykopę pod numerem $S 22$ podając przykłady występowania tematu w kazaniach Benedykta Brittanica OP, Marka de Summa Ripa oraz Piotra Hieremiae $\mathrm{OP}^{37}$. Święto wypadające 25 listopada powtarza się jako festum fori w większości polskich statutów synodalnych począwszy od statutów krakowskich biskupa Nankera z 1320 r. a skończywszy na synodzie łęczyckim z 1523 r., kilka razy oznaczone w rycie semiduplex, festum duplex oraz powiązane $\mathrm{z}$ postem $\mathrm{i}$ wigilią ${ }^{38}$. Oznaczone jest również w niedawno wydanym „Kolektarzu wawelskim” sprzed 1526 r. oraz wcześniejszych źródłach liturgicznych krakowskich, m.in. w brewiarzu z $1443 \mathrm{r}$. i późniejszych z pierwszej połowy XVI wieku ${ }^{39}$. Oczywiście nie można z tego wysuwać wniosków o pochodzeniu Kazań, gdyż święto Katarzyny zostało przyjęte w kościele krakowskim z liturgii rzymskiej.

W Kazaniach znajdziemy zresztą inne przykłady translacji łacińskich cytatów z Pisma św. („Kazanie IV: Na Narodzenie Pańskie”, wg Za 9, 9,) a w „Kazaniu V: Na objawienie Pańskie” jest nim być może kolejna perykopa „Ubis est, qui natus est rex Iudeorum” z Mt, 2, 2 przełożona dalej po polsku ${ }^{40}$. W „Kazaniu VI: Na Oczyszczenie NMP” autor po przytoczeniu po lacinie (perykopy?) Lk. 2, 30: „<V >iderunt oculi mei salutare tuum”, wyłożył wprost, „Awa tych słow <wykład z języ $>$ ka łacińskiego w polski jeść taki: Widzieli, prawi, oczy moi <zbawienie twoje>, toczu syna twego"41.

Podobny przykład reprezentuje niedawno wydane ponownie „Kazanie na Wszech Świętych" poprzedzone obszernym wstępem łacińskim z fragmentem łacińskiego verba thematum z Ap. 7, 9: „post haec vidi tur-

${ }^{36}$ P. Stępień, Z literatury religijnej polskiego średniowiecza. Studia o czterech tekstach. Kazanie na dzień św. Katarzyny, Legenda o św. Aleksym, Lament świętokrzyski, Żottarz Jezusow, Warszawa 2003, s. 15-16.

37 J. B. Schneyer, Repertorium der lateinischen Sermones des Mittelalters für die Zeit von 1350 - 1500. Nach der Vorarbeit von J. B. Schneyer, L. Hödl, W. Knoch, Ruhr - Universität Bohum, Münster - Aschendorff 2001 (CD ROM).

38 I. Skierska, Obowiazek mszalny, s. 187.

${ }^{39}$ Kolektarz wawelski sprzed 1526 roku. Świadek liturgii Kościota krakowskiego w XV, XVI $i$ XVII wieku, wyd. X. Sz. Fedorowicz, Kraków 2007 (Monumenta Sacra Polonorum, t. 2), s. 93, 402 .

${ }^{40}$ Kazania świętokrzyskie. Nowa edycja.., s. 252, 256.

${ }^{41}$ Tamże, s. 260. 
bam magnam quam dinumerare nemo poterat ex omnibus gentibus et tribubus", aczkolwiek zapowiadającym właściwy temat kazania z Mt. 5, 1-12: „videns autem turbas ascendit in montem et cum sedisset accesserunt ad eum discipuli eius”, który został następnie w całości bez skrótów przełożony na język polski ${ }^{42}$.

„Kazanie II: Na dzień Św. Katarzyny” jedyne szczęśliwie zachowane prawie w całości, stanowi zresztą w tej mierze najbardziej interesującą podstawę do analiz. Zawiera długie łacińskie fragmenty, z których te poprzedzone charakterystycznym zwrotem „Nota” trzeba uznać za szczególnie cenne dla heurystyki Kazań. Zwrot ten trzeba czytać w imperatywie i w znaczeniu zgodnym $\mathrm{z}$ jedną z glos z XV, gdzie przełożono „notemus < baczmy> "43. Takich not jest w tym kazaniu 6, w kolejności: „Nota in vita sua in principio...", "Nota de quinquaginta sapientibus...", „Require superius in sermone...”, „Nota, quomodo surrexit...”, „Hic nota de martirio regine...” oraz „Nota ergo, quomodo imperator Maxencius...”. Większość odnosi się do żywota św. Katarzyny w intencji poszerzenia i uwypuklenia w praktyce werbalnej wybranych momentów z żywota świętej. „Require superius in sermone...”, to również „wewnętrzna" wskazówka dla kaznodziei, aby skorzystał z wcześniejszego kazania w zbiorze. Tak jak sugerowałem wcześniej, stanowią one rodzaj markerów, które jak się zdaje, odkrywają typ transmisji zachowanego tekstu. Wszystko wskazuje na to, że mogą one należeć do grupy tzw. wskazówek homiletycznych, które wyodrębnił David d'Avray, badacz tego zagadnienia, czyli zwrotów, odsyłaczy do innych kazań w kolekcji lub instrukcji w tekście przeznaczonych bezpośrednio dla czytelnika - kaznodziei, a dopiero w drugiej fazie dla audytorium dotyczących sposobu wygłaszania lub będących śladem relacji między tekstem zapisanym a wygłaszanym, co miało wykluczać ich przeznaczenie tylko do prywatnej lektury ${ }^{44}$. Takie wskazówki homiletyczne D.L. d'Avray uważał za ślad kazań wzorcowych. Przytoczmy kilka ciekawszych przykładów z pracy d'Avray'a. Przy okazji połajanek przeciwko hazardowi w jednej z mów cytowanych przez powołanego autora, kaznodzieja radził „Zwróć uwagę” (zdanie zaczyna od typowego „nota, quamvis”), „choć hazardzista czasami coś wygra, nigdy jednak nie trwa to długo, lecz zwykle na koniec wyganiają go

${ }^{42}$ Kazanie na dzień Wszech Świętych (tzw. praskie), opr. B. Mazurkiewicz, W. Wydra, P. Stępień, W. Twardzik, E. Belcarzowa, Poznań 2008, s. 12-15.

${ }^{43}$ Stownik taciny średniowiecznej w Polsce, red. M. Plezia, t. 6, Wrocław 1988, s. 755.

${ }^{44}$ D.L. d'Avray, The Preaching of the Friars. Sermons diffused from Paris before 1300, Oxford 1983, s. 105-108, przyp. 1. 
ogołoconego z karczmy, tak też jest z naszym światem”. Zdanie to kończy w imperatywie: „Porównaj i wyłóż (Compara et expone)” 45 . Spośród zaś odsyłaczy wymienia zwroty typu: „,require plenius supra in primo sermone dominice secundo in quadragesima”, „Si vis loqui de confessione, require de ea in illo sermone ultime dominice”, „Hoc habes expositum dominica in ramis palmarum”, lub „De adventu huius regis nota in ultima dominica ante adventum”. Inne zaś brzmią jak zwięzłe porady: „Dic breviter hystoriam illam”, „Nota, quo sequitur de parabola”, „fac VII proprietates nubis circa VII peccata mortalia"46.

Nie znamy kompletnego tekstu Kazań świętokrzyskich, ale na zasadzie pars pro toto, możemy wyrokować, że takich wskazówek homiletycznych w kolekcji świętokrzyskiej było znacznie więcej. Szczęśliwie zachowane „Kazanie II: Na dzień św. Katarzyny” może zatem ujawniać ogólną cechę Kazań przynajmniej w tym rękopisie i poświadczać ich modelowy charakter z przeznaczeniem do wygłoszenia, co oczywiście nie wyklucza prywatnej pobożnej lektury, w każdym razie był to żywy tekst otwarty na rozbudowę, uzupełnienia i korektę w czasie ekspozycji werbalnej.

Podobne zwroty zawierają kazania z tzw. kolekcji Piotra z Miłosławia z XV w. oraz w Postylli Mikołaja Wiganda ${ }^{47}$ i wielu innych. Fragmenty typu „Nota” są tam wręcz nagminnie wkomponowywane lub najczęściej dopisywane do kazań na końcu. Można je podzielić na kilka grup tematycznych: noty dotyczące kwestii liturgicznych (np. wykazy wyłączonych od komunii wielkanocnej, noty o sakramencie chrztu i małżeństwa, o święceniu świec w święto Oczyszczenia NMP), hagiograficznych (legenda, passio, miracula), prawniczych (noty o dziesięcinach, o ekskomunice i interdyktach) oraz teksty pieśni liturgicznych, ponadto codzienne

45 Tamże, s. 108, przyp. 2.

46 Tamże, s. 106-107. Por. też D. Wójcik, W. Zega, Stanistawa ze Skarbimierza Kazanie uniwersyteckie Nihil tuleritis in via, „Przegląd Tomistyczny”, 14:2008, s. 102: cytują przykład podobnej wskazówki homiletycznej z kazania Skarbimierczyka: „luxta quem sensum potest de bonis illud Isaiae 35 accipi". Inny fragment takiej uwagi nie przeznaczonej do wygłoszenia, gdyż stanowiącej przestrogę dla innych kaznodziejów, aby ostrożnie cytowali legendę o św. Wawrzyńcu, przytoczył z kazania z poł. XV w. z kolekcji Sermones de tempore et de sanctis Pawła z Zatora (?), z dawnego rpsu Cesarskiej Publicznej Biblioteki Petersburskiej Lat. I Folio 475, A. Brückner, Kazania średniowieczne, cz. 3, s. 10, s. 42-43; K. Bracha, Nauczanie kaznodziejskie, w Polsce późnego średniowiecza. Sermones dominicales et festivales $z$ tzw. kolekcji Piotra $z$ Mitostawia, Kielce 2007, s. 314: „videtur enim, quod ista de abstraccione pueri, perdicione et transformacione demonis in puerum simplici populo non sunt dicenda (...) Sed pro communi populo sic incipe legendam".

${ }^{47}$ Wrocław, Oss., rps 1629/II: Mikołaj Wigand, Postilla evangelia de sanctis, f. 30vb, 36ra, 36va, 44vb, 46ra, 47vb, 49va-b, 69rb. 
modlitwy w języku polskim lub teksty mnemotechniczne, np. o wzorcowej spowiedzi, wierszowane wykazy grzechów głównych i dekalogi. Te ostatnie stanowiły rudymenta wiary i były wykorzystywane przez kaznodzieję w czasie exhortacji w trakcie akcji kaznodziejskiej, niekiedy również w samym kazaniu. Należą do nich również teksty apokryficzne lub apokryfizujące, np. „Dialogus Beatae Mariae et (Ps.) Anselmi de passione Domini” czy „Historia assumpcionis Virginis Marie”48. Wszystkie pełniły rolę tekstów pomocniczych wykorzystywanych przez mówcę w liturgii kazania zarówno tuż przed jego wygłoszeniem, w trakcie jak też zaraz po zakończeniu właściwej mowy. Ulotny charakter takich not poświadcza fakt, że nie wszystkie były kopiowane. Porównanie czterech kopii wspomnianej kolekcji Miłosławianina dowodzi, że w każdym rękopisie jest inny zestaw, inna liczba not i podobnych dodatków. Był to bowiem element indywidualnego wyboru kopisty-kaznodziei, odpowiadający osobistym potrzebom i kompetencji predykanta.

Jeśli w świętokrzyskim „Kazaniu na dzień św. Katarzyny” anonim zwraca uwagę na wybrane wątki z żywota św. Katarzyny, to w wielu kazaniach de sanctis, właściwe kazanie kończy dopisana do sermo w całości obszerna legenda o świętym, którą predykant mógł dowolnie wykorzystać w praktyce werbalnej. Legendy wpisywano w kodeksach kaznodziejskich również poza kontekstem kazania, w taki autonomiczny sposób kopista wpisał Legendę o św. Katarzynie zaraz po Postylli Mikołaja Wiganda z rękopisu Oss. 1629/II, choć w samej Postylli kazania na ten dzień brakuje ${ }^{49}$. Podobne przykłady przynoszą m.in. badania Tomasza Ossowskiego podjęte nad kazaniami de sancto Adalberto ${ }^{50}$.

Podobną funkcję wskazówek homiletycznych pełnią odsyłacze do poprzednich kazań, marginalne noty z alternatywną wersją bieżącego fragmentu kazania od słów „vel sic” lub odniesienia wyjaśniające ryt mszy, ponadto liczne pouczenia dla kaznodziejów, np. o trzech sposobach ni-

${ }^{48}$ Dialogus Beatae Mariae et (Ps.) Anselmi de passione Domini, wyd. Patrologia Lati$n a$, ed. J.-P. Migne, t. 159, Parisiis 1854, s. 271-290, to dialog epiczny powstały w XII w. Natomiast Historia assumpcionis Virginis Marie, jest u Jakuba de Voragine, Legenda aurea, wyd. Th. Graesse, Vratislaviae 1890, s. 504-526 oraz w tłum. J. Pleziowa, Zlota legenda, Warszawa 1983, s. 339-348. Tradycję apokryficzną Historia assumpcionis... wraz z tekstami w tłum. zestawiają Apokryfy Nowego Testamentu, cz. 2, red. i tłum. M. Starowieyski, Kraków 2003, s. 777-834, 896-902. Por. K. Bracha, Predigerkodex als Pastoralhandbuch. Am Beispiel der Sermones dominicales et festivales der sogennanten Sammlung von Petrus von Mitostaw, „Medieval Sermon Studies“, 52:2008, s. 75-80; tenże, Nauczanie kaznodziejskie, s. 101-104.

${ }^{49}$ Wrocław, Oss., rps 1629/II, f. 152vb-153vb.

${ }^{50}$ T. Ossowski, Kazania de sancto Adalberto z XV wieku jako nośnik pamięci historycznej (w druku). 
welowania błędów w kazaniach ${ }^{51}$. Wszystko to pozostawiało kaznodziei niemałe pole na modyfikację tekstu w ekspozycji werbalnej i własną inwencję. Zapisane kazanie było bowiem tylko propozycją, modelem, formularzem, a nie „gotowcem” do odtworzenia. Niekiedy dla ułatwienia kaznodzieja podkreślał w tym celu czerwoną linią całe fragmenty tek$\mathrm{stu}^{52}$. W ten sposób kodeks kaznodziejski zastępował mówcy całą bibliotekę pełniąc rolę uniwersalnego podręcznika do katechezy i ewangelizacji ${ }^{53}$.

Reasumując, wspomniane „Kazanie o św. Katarzynie” może dowodzić, że znany nam rękopis Kazań jest kopią kopii, jak trafnie sugeruje Wiesław Wydra (s. 47-51), pytanie tylko jaką techniką pozyskanej? Najwięcej przesłanek wydawałoby się przemawiać za kopią kopii sporządzonej metodą reportatio. Technika reportatio jest jednak nadal kwestią żywej debaty naukowej nie tylko ze względu na sposób wykonywania not, lecz przede wszystkim relacji między różnymi wersjami tekstów reportowanych i niereportowanych oraz rodzących się z tego pytań o atrybucję, wiarygodność przekazu, transmisję i cyrkulacje tekstów kazańn ${ }^{54}$. Reportatio to stara technika, która odżyła w XII w. w szkole św. Wiktora. Tamtejsi studenci oddawali do sprawdzenia swemu mistrzowi własne notatki, który je następnie korygował dla wierności przekazu własnych wykładów. Technika ta została następnie przejęta przez środowiska kaznodziejskie. Z czasem z takich reportationes korzystano dalej jak z podstawy, co potwierdziły studia Nicole Bériou, Louisa J. Bataillona, Jacqueline Hamesse oraz Jacquesa-Guy Bougerola. Z reportationes korzystali nawet sami autorzy - kaznodzieje, m.in. św. Bonawentura i św. Bernard,

${ }^{51}$ Sermo 33, [w:] Sermones dominicales et festivales z tzw. Kolekcji Piotra z Mitostawia, Warszawa, BN, rps 3021, f. 78vb; Sermo 29, [w:] tamże, f. 68 va; Sermo 33, [w:] tamże, f. 79 ra; Sermo 83, [w:] tamże, f. 251 va-b. Por. D. Roth, Die mittelaterliche Predigttheorie und das Manuale Curatorum des Johan Ulrich Surgant, Basel und Stuttgart 1956 (Basler Beiträge zur Geschichtswissenschaft, red. E. Bonjour, W. Kaegi, t. 58), s. 70. Mieszczą się w tym również zwroty audialne, za które można uznać słowa bezpośrednio skierowane do słuchaczy, typu „Carisssimi hodie ebdomadam audivistis” lub „hodie vero audiatis”, bądź „Ewangelio hodierno, quod audivistis”, tudzież słowa kaznodziei w 1 lub 2 os. 1. poj., gdy chciał spotęgować narzędzia perswazyjne, stosując zabieg nazywany przez Bonawenturę „modus affectuosus".

52 Por. A. T. Thayer, The Postilla of Guillermus, s. 64; W. Williams-Krapp, Mittelalterliche deutsche Heiligenpredigtsammlungen und ihr Verhältnis zur homiletischen Praxis, [w:] Die deusche Predigt im Mittelalter, s. 353.

53 Por. K. Bracha, Predigerkodex als Pastoralhandbuch, s. 75-80.

${ }_{54}$ J.-L. Bataillon, Approaches to the Study of Medieval Sermons, [w:] tenże, La prédication au XIIIe siècle en France et Italie. Etudes et documents, Variorum, Aldershot 1993 , s. 21; E. Potkowski, Pisarz i jego dzieło w spoteczeństwie Sredniowiecznym, [w:] tegoż, Książka i pismo w średniowieczu, Pułtusk 2006, s. 290-311. 
który używali reportationes swoich kazań spisanych przez osobistych sekretarzy jako brudnopisu w celu sporządzenia ostatecznej redakcji kazania $^{55}$. Piotr z Limoges zaś spisał własne reportationes i rozprowadził je w kopiach rękopiśmiennych ${ }^{56}$. N. Bériou w oparciu o analizę kazań wygłoszonych przez franciszkanina Jacquesa de Provins w kościele parafialnym św. Pawła wyodrębniła dwa stadia redagowania reportationes: notatki na brudno oraz czystopis. Jej analiza dowodzi, że reportationes w obydwu fazach nie były literalnym odzwierciedleniem ekspozycji werbalnej, lecz dwiema fazami kolejnych redakcji. Już w brudnopisie kopista latynizował tekst, pozostawiając część po francusku, zachował jednak strukturę mowy, słowa klucze w cytatach, a wszystko kosztem słownictwa francuskiego. Można to wyjaśnić powodami ekonomicznymi i technicznymi, albowiem kopista miał płacone od ilości słów, a po łacinie pisał szybciej i łatwiej niż we własnym języku, wyjaśnia N. Bériou, której ważne ustalenia niemal literalnie w tym miejscu przywołuję $e^{57}$. Gdy zaś konwertował tekst reportatio do wersji czystopisu zatajał niektóre słowa francuskie, a kolejne pomijał lub dalej przekładał na łacinę, z kolei w innym miejscu wprowadzal nowe fragmenty francuskie, co ciekawe w formie rymowanej lub przysłowia, które zdołał zapamiętać. W ten sposób

${ }^{55}$ L. Meier, Über den Zeugniswert der „Reportatio”, „Archiv für Kulturgeschichte”, 36:1954, s. 1-8; G. Müller, La „Reportatio”, „Salesianum”, 21:1959, s. 647-659; J. Longère, La prédication médiévale, Paris 1983, s. 159; R. Rusconi, Reportatio, „Medioevo e Rinascimento", t. 3, 1989, s. 7-36 (g1., s. 17); J. Hamesse, La méthode du travail des reportateurs, tamże, s. 51-68; N. Bériou, La reportation des sermons parisiens à la fin du XIII ${ }^{e}$ siècle, tamże, s. 87-124; tejże, Latin and the Vernacular, s. 270; M. B. Parkes, Tachygraphy in the Middle Ages. Writing Techniques Employed for "Reportationes» of Lectures and Sermons, tamże, s. 159-169; L.-J. Bataillon, Status quaestionis sur les instruments et les techniques de travail de $S$. Thomas et $S$. Bonaventure, [w:] 1274, année charniére, Paris 1977 (Bibliotheca Franciscana Scholastica Medii Aevi, 27), s. 647-657; B. M. Kienzle, Introduction, s. 173; D. L. d'Avray, The Preaching of the Friars, s. 97-98; J. Miethke, Die mittelalterliche Universitäten und das gesprochene Wort, München 1990 (Schriften des Historischen Kollegs. Vorträge 23), s. 25. Wydaje się, że o korygowaniu reportationes własnych kazań mówi również św. Grzegorz w liście Ad Secundinum Tauromenitanum episcopum, [w:] Gregorius Magnus, XL Homeliarum in Evangelia libri duo, wyd. Patrologia Latina, ed. J.-P. Migne, t. 76, Parisiis 1849, s. 1075 (wyd. w tłum. św. Grzegorz, Homilie na Ewangelie, Warszawa 1998, s. 29): „Et quarumdam quidem dietata expositio, assistente plebe, est per notarium recitata; quarumdam vero explanationem coram populo ipse locutus sum, atque ita ut loquebar excepta est. Sed quidam fratres, sacri verbi studio ferventes, antequam ad propositum modum ea quae dixeram subtili emendatione perducerem, transtulerunt. Quos recte ego quasi quibusdam famelicis similes dixerim, qui prius escas edere appetunt quam plenius excoquantur".

56 J.-L. Bataillon, Approaches to the Study, s. 20.

${ }^{57}$ N. Bériou, Latin and the Vernacular, s. 273; A. Birkenmajer, Pecja, Kraków 1936 (odb. z „Przeglądu Bibliotecznego”, 10:1936), s. 9. 
tekst zanotowany w czasie kazania stanowił rodzaj matrycy do dalszych przekształceń, a niektóre konkretne zapamiętane słowa łacińskie miały stanowić podstawę do zrekonstruowania tekstu. Wszystko to osłabia wiarygodność wernakularnych reportacji, które w kolejnych swoich mutacjach podlegały zmianom redakcyjnym dla nadania cech retorycznych i konstrukcyjnych, a w rezultacie działo się to kosztem oryginalnego języka kazania, czyli języka narodowego.

Innymi słowy, kaznodzieje, jak sugeruje autorka, nie mieli zamiaru czynić z języka wernakularnego konkurencji wobec łaciny, czyli nobilitować dzięki utrwalaniu w piśmie. Łacina była nie tylko językiem nauki, lecz przede wszystkim językiem świętym, natchnionym, ponadto oznaką prestiżu dla samych kaznodziejów i ich przewagi kulturowej, intelektualnej, ale też kluczem do monopolu. N. Bériou sugeruje, że bilingwizm kazań XIII w. przemawia za traktowaniem łaciny i języka francuskiego jako języków bliźniaczych, próbą ożywienia łaciny i dopasowania jej na wzorcu wernakularnym do zastosowań przed prostym audytorium jako swego rodzaju Gebrauchsprosa. Mieczysław Mejor i Tomasz Mika oraz kilku wcześniejszych autorów mówi w tym kontekście o łacinie jako metajęzyku, gdzie łacina jest wpisana w „,konstrukcję retoryczno-symboliczną kazań” oraz tworzy „dodatkowy efekt artystyczno-perswazyjny” i że obydwa języki funkcjonują komplementarnie i uzupełniają się ${ }^{58}$. Ewa Ostrowska sugerowała w tym miejscu, że jest to wszystko ujęte w stylistyce charakterystycznej dla ars dictandi naginanej do systemu retorycznego ${ }^{59}$. Skądinąd wiemy, że część kazań modelowych była rytmizowana, co zresztą zalecały podręczniki kaznodziejskie ${ }^{60}$ i co spełniało zarówno walor mnemotechniczny jak też stylistycznego ornatus ${ }^{61}$. Opinie te wypowiedziane $\mathrm{z}$ punktu widzenia filologicznego korespondują z poglądem N. Bériou o językach bliźniaczych (twin languages). Łacina stanowi

${ }^{58}$ M. Mejor, Łacina w Kazaniach świętokrzyskich, s. 86; T. Mika, Tajemnice „Kazań świętokrzyskich”, s. 15; Z. Krążyńska, T. Mika, Języki „Kazań świętokrzyskich” [http://www.staropolska.pl/sredniowiecze/opracowania/Mika.html].

${ }^{59} \mathrm{E}$. Ostrowska, O artyzmie polskich średniowiecznych zabytków językowych (Bogurodzica, Kazania świętokrzyskie, "Postuchajcie, bracia mita», Kraków 1967, s. 86, 95 . O ars dictaminis zob. ostatnio T. Michałowska, „Ars dictaminis” w Polsce średniowiecznej. Literackie treści doktryny, [w:] Septem artes w ksztattowaniu kultury umystowej w Polsce średniowiecznej, red. T. Michałowska, Wrocław 2007, s. 41-74.

${ }^{60}$ Thomas Waleys, De modo componendi sermones, wyd. Th.-M. Charland OP, Artes praedicandi, s. 152-154.

${ }^{61}$ D. L. d'Avray, The Preaching of the Friars, s. 248-254. O mnemotechnice w kazaniach ostatnio m.in. R. Wójcik, The Staging of Memory: Ars memorativa and the Spectacle of Imagination in late Medieval Preaching in Poland, [w:] The Making of Memory in the Middle Ages, ed. by L. Doležalová, Leiden-Boston 2010, s. 87. 
zatem narzędzie „uświęcające” mowę, nadając jej powagi wypowiedzi sakralnej, performatywnej i perswazyjnej. Skoro bowiem kazanie to mowa święta, płynąca z ust samego Stwórcy za pośrednictwem kaznodziei ${ }^{62}$, to przynajmniej niektóre jej elementy w języku natchnionym, w języku Biblii winny spełniać walor, który można porównać do efektu sublimacji mowy.

Co zatem można wnioskować o genezie świętokrzyskiego zabytku w świetle powyższych stanowisk i przy uwzględnieniu różnych uwarunkowań kultury piśmiennej europejskiego średniowiecza?

Jeśli Kazania świętokrzyskie to w istocie kopia kopii pozyskana metodą reportacji, to jest to odpis ze słuchu poddany następnie zabiegom redakcyjnym do dalszego wykorzystania w lekturze i w mowie. O wtórności przekazu świadczyć mogą nie tyle partie łacińskie Kazań, co do których nie mamy pewności, jak się tam znalazły (czy w istocie można się zgodzić z tezą, że były one wcześniej w pierwotnej kopii na marginesach, czy pojawiły się tam na innej drodze redakcyjnej?), lecz chyba raczej obecność owych „not homiletycznych”, których nie da się chyba pogodzić z techniką reportatio. Za reportacyjnym pochodzeniem Kazań może przemawiać również wersja językowa, nie wykluczone, że pierwotnie zapisana na tabliczkach woskowych, jak sugeruje W. Wydra, aczkolwiek literatura sygnalizuje wiele subtelności i różnych sposobów zapisywania kazań ex auditu ${ }^{63}$. Można również pytać, czy ta właśnie technika reportatio nie zmusiła pierwszego pisarza do zastosowania wzorem łaciny systemu abrewiacji w obrębie języka polskiego, systemu tak mocno rozbudowanego, że jak pisze W. Wydra, ,takiego nasycenia skrótami nie spotykamy już w żadnym innym średniowiecznym zabytku piśmiennictwa polskiego (a także czeskiego)" "64. Faktem jest, że w świetle statystyki sporządzonej w najnowszej edycji przez Katarzynę Skowronek na 1618 wszystkich słów w tekście Kazań, ok. 30\% słów zostało zapisanych w formie skróconej ${ }^{65}$. Można zatem zgodzić się z autorem tych analiz, że należy się domyślać istnienia w Polsce $\mathrm{w}$ tych czasach wyspecjalizowanych skryptoriów, które takim systemem abrewiacji staropolskiej biegle się posługiwały. Sprawa zaś tabliczek woskowych i ich roli w kulturze piśmiennej średniowiecza polskiego, zagadnienia niezwykłej wagi, wyma-

${ }^{62}$ K. Bracha, Nauczanie kaznodziejskie, s. 105 in.

${ }^{63}$ W. Wydra, Wokót fenomenu, s. 56 , przyp. 80.

64 Tamże, s. 51.

${ }^{65}$ K. Skowronek, Kazania świętokrzyskie - liczby i stowa, [w:] Kazania świętokrzyskie. Nowa edycja..., s. 168; W. Wydra, Wokót fenomenu, s. 51. 
ga oddzielnych, pogłębionych badań. Przyjmuje się, że w technice reportatio do momentu większego rozpowszechnienia pergaminu posługiwano się tabliczkami woskowymi. Później zaś taką rolę mógł przejąć pergamin, o czym może świadczyć m.in. ikonografia, np. scena z końca XV w. (Walencja, Museo Provincial) z przedstawieniem Wincentego Ferrera na ambonie i postaci jednego ze słuchaczy kazań, który siedząc u stóp spisuje mowę raczej nie na tabliczkach ${ }^{66}$. Być może są to wymieniane w źródłach pisanych membrana lub pellis (in pelle exaratum ${ }^{67}$. Śladu techniki reportatio domyślał się również już wcześniej m.in. Mieczysław Mejor $^{68}$.

Jeśli zatem ta sugestia jest trafna, to Kazania w swej zachowanej wersji byłyby przykładem reportacji, należącej do drugiej wyodrębnionej przez N. Bériou grupy reportacji czysto-piśmiennej, czyli odpisu reportacji brudno-piśmiennej, poddanej dalszym zmianom redakcyjnym. Technika taka nie była chyba odosobniona w naszej strefie geograficznej, skoro na ziemiach polskich znano kopiowanie tekstów w tym również kazań metodą pod dyktando (ad pennam), a nawet jak się przypuszcza, stosowano ją częściej niż popularny na Zachodzie system pecji. Świadczą o tym określenia w kolofonach rękopisów z XV w. typu: „est reportatum hoc opus per manus” lub „reportatur ... per manus” zebrane przez Edwarda Potkowskiego ${ }^{69}$. Świadectwem ze środowiska kaznodziejskiego nieodległej czeskiej Pragi jest zaś wzmianka o dyktowaniu

${ }^{66}$ P. T. Dobrowolski, Wincenty Ferrer kaznodzieja ludowy późnego średniowiecza, Warszawa 1996 (Ilustracja na końcu książki bez numeracji). Inne przykłady u R. Rusconi, Reportatio, s. 17 , przyp. 50, który akcentuje ubóstwo źródeł ikonograficznych z motywem tabliczek woskowych. W słynnym Kodeksie Manessów z I poł. XIV w. ze zbiorów Bibliotheca Palatina Heidelberg Cpg 848 poeta-minnesinger Reinmar von Zweter dyktuje swoje pieśni, a spisują je obok kobieta na zwoju oraz skryba na tabliczkach woskowych. Por. E. Potkowski, Balderyk z Bourgueil i jego poetycka korespondencja, [w:] Scriptura, diploma, sigillum. Prace ofiarowane Profesorowi Kazimierzowi Bobowskiemu, red. J. Zdrenka, J. Karczewska, Zielona Góra 2009, s. 249, Ryc. 10.

${ }^{67}$ R. Rusconi, Reportatio, s. 18 , przyp. 51.

${ }^{68}$ M. Mejor, Pochodzenie Kazań świętokrzyskich - trop filologiczno-muzykologiczny, [w:] Amoenitates vel lepores philologiae, red. R. Laskowski, R. Mazurkiewicz, Kraków 2007, s. 223.

${ }^{69}$ E. Potkowski, Ksiązka rękopiśmienna w kulturze Polski średniowiecznej, Warszawa 1984, s. 89-90; Kopiści i kolofony rękopisów średniowiecznych ze zbiorów polskich, t.1: Bilioteki Warszawy, Warszawa 1993 (Manuscripta Medii Aevi Poloniae. Polska pisząca w średniowieczu), s. 42, 45, 49; G. Powitz, Modus scolipetarum et reportatistarum. Pronuntiatio and Fifteenth Century University Hands, „Scrittura e civiltà”, 12:1988, s. 201-211. O systemie pecji, por.: A. Birkenmajer, Pecja, passim; D. L. d'Avray, The Preaching of the Friars, s. 99. O kontrowersjach w ocenie tej metody (powolnego dyktowania ad pennam, tractim) w środowisku uniwersyteckim na rzecz szybkiego mówienia (raptim), aby student miał czas do myślenia i notowania tylko najważniejszych treści, por. J. Miethke, Die mittelalterliche Universitäten und das gesprochene Wort, s. 23. 
zatrudnionym kopistom własnych kazań przepisanych w przeddzień własnoręcznie przez znanego czeskiego kaznodzieję Jana Milicza z Kromierzyża (studentibus ad ingrossandum et aliis scribentibus pronunciare" $)^{70}$.

Oczywiście różnica polega w tym przypadku na okolicznościach i intencjach, co nie pozostawało bez wpływu na charakter kopiowanego w ten sposób tekstu. W tekstach pod dyktando nie ma mowy o spontaniczności przekazu, skrótach lub parafrazach. W świetle ówczesnych statutów uniwersyteckich z Wiednia dyktowanie miało być „wierne i poprawne, powolne i z wyraźnie zaznaczonymi paragrafami, początkowymi literami rozdziałów, znakami interpunkcyjnymi" 71 .

Przenikanie się łaciny z elementami not homiletycznych wyklucza również, jak się wydaje, przynależność do lektury dla celów pobożnej medytacji, jednakże przewaga języka wernakularnego może miast reportacji sugerować jeszcze inne pochodzenie, a mianowicie kopie tekstu napisanego przez kaznodzieję, gdy przygotowywał mowę, i zachowanego jako memorandum. Musimy bowiem pamiętać, że makaronizacja jest możliwa w obydwie strony także jako adaptacja wersji łacińskiej do języka wernakularnego, o czym już wyżej wzmiankowano ${ }^{72}$.

Jedno jest pewne, momenty „ścierania się łaciny z językiem polskim”, według sformułowania Marka Skwary ${ }^{73}$, lub tego, co z kolei M. Mejor określił mianem funkcjonalnej dyglosji ${ }^{74}$, należą do najciekawszych cech Kazań, pomijane w badaniach nadal „oczekują na swoich interpretato-

${ }^{70}$ P. C. A. Morée, Preaching in Fourteenth-Century Bohemia. The Life and Ideas of Milicius de Chremsir, s. 39-40.

${ }^{71}$ E. Potkowski, In scola scriptum. Szkoła jako miejsce działalności pisarskiej w średniowieczu, [w:] tegoż, Książka i pismo w średniowieczu, Pułtusk 2006, s. 149. Terminologię źródłową: reportare, pronuntiare, dictare analizowali J. Hamesse, Le vocabulaire de la transmission orale des tetes, [w:] Vocabulaire du livre et de l'écriture au moyen âge, red. O. Weijers, Turnhout 1989, s. 168-194 oraz G. Powitz, Modus scolipetarum et reportisarum, s. 201-211. J. Miethke, Die mittelalterliche Universitäten und das gesprochene Wort, s. 23-25, przyp. 52, uniwersyteckie reportatio rozumie jako „<freie $>$ Vorlesungs-bzw. Disputationsnachschrift, nicht für die Mittschrift im Gruppendiktat der pronunciatio", a więc bardziej jako raptim niż tractim, jednocześnie akcentuje przypadki techniki mieszanej. Dziękuję w tym miejscu za wskazówki bibliograficzne i konsultację prof. Edwardowi Potkowskiemu.

${ }^{72}$ Zob. wyżej przyp. 24. Por. też ciekawą uwagę E. Belcarzowej, Jak w XV wieku ttumaczono lacińskie kazania?, s. 167, że kopista makaronizował tekst pierwotnie łaciński, albowiem w tekście kopiowanym wciągał glosy in extenso obok objaśnianych słów łacińskich, a niekiedy zamiast nich.

${ }^{73}$ M. Skwara, Struktura i sposoby argumentacji w Kazaniu na dzień św. Katarzyny, [w:] Kazania swiętokrzyskie. Nowa edycja..., s. 160.

${ }^{74}$ M. Mejor, Łacina w Kazaniach świętokrzyskich, s. 87. 
rów”. Czy są one śladem relacji między odbiorcą a nadawcą Kazań, kluczowym zagadnieniem w genezie tekstu, stanowiącym nadal przedmiot otwartej dyskusji oscylującej między wykształconymi elitami a masami słuchaczy z ludu, czy tylko śladem skomplikowanej i zawiłej techniki reportacyjnej oraz maniery pisarskiej średniowiecznego kopisty- kompilatora, to pytania kluczowe. W każdym razie obserwacja Kazań z perspektywy dwujęzycznego tekstu homiletycznego i średniowiecznej artis compilandi, wydaje się obiecującym kierunkiem badawczym w przyszłości. W świetle uwag jednego z badaczy mamy bowiem obowiązek szukać śladów relacji między wygłoszeniem, a spisaniem kazania ${ }^{75}$. Fragmentaryczność zabytku i brak rodzimej podstawy do porównań wymaga jednak uwzględnienia obszernego materiału komparatystycznego.

\section{Summary}

\section{Latin Annotations in the Holy Cross Sermons}

Krzysztof Bracha discusses the 29 Latin annotations to be found within the old-Polish text of the Holy Cross Sermons. Considering that the extant fragments of the Sermons constitute only a fraction of the lost original, it is obvious that the whole collection in its complete state must have encompassed many more such annotations. Hence the original collection belonged to the type of macaronic sermons. According to regulations issued by medieval synods, sermons for the general public (ad populum), were to be delivered in the vernacular. The discussed annotations break up into two categories: gospel pericopes, translated into Polish or not, and marginal notes, which served as a homiletic aid for the preacher. The annotation in the "Sermon for St. Catharine's Day" may suggest that the extant fragments are in fact a copy of a copy. Comparisons with numerous other manuscripts containing sermon collections bring Bracha to the conclusion that the discussed copy was prepared in accord with the reportatio technique. Hence the Holy Cross Sermons would be the result of writing down of a text delivered by word of mouth, and only afterwards submitted to editorial revisions. Bracha postulates further research of this monument with the consideration of its bilingualism and in view of the medieval ars compilandi.

75 U. Störmer, Möglichkeiten der Gattungsabgrenzung bei auslegenden katechetischen Texten, [w:] Die deutsche Predigt, s. 347. 